\title{
Paclitaxel in self-micro emulsifying formulations: oral bioavailability study in mice
}

\author{
Roos L. Oostendorp • T. Buckle • G. Lambert • \\ J. S. Garrigue • J. H. Beijnen • J. H. M. Schellens • \\ O. van Tellingen
}

Received: 10 January 2010 / Accepted: 9 March 2010 /Published online: 13 April 2010

(C) The Author(s) 2010. This article is published with open access at Springerlink.com

\begin{abstract}
Summary The anticancer drug paclitaxel is formulated for i.v. administration in a mixture of Cremophor EL and ethanol. Its oral bioavailability is very low due to the action of Pglycoprotein in the gut wall and CYP450 in gut wall and liver. However, proof-of-concept studies using the i.v. formulation diluted in drinking water have demonstrated the feasibility of the oral route as an alternative when given in combination with inhibitors of P-glycoprotein and CYP450. Because of the unacceptable pharmaceutical properties of the drinking solution, a better formulation for oral application is needed. We have evaluated the suitability of various self-micro emulsifying oily formulations (SMEOF's) of paclitaxel for oral application using wild-type and P-glycoprotein knockout mice and cyclosporin A (CsA) as P-glycoprotein and CYP450 inhibitor. The oral bioavailability of paclitaxel in all SMEOF's without concomitant CsA was low in wild-type mice, showing that this vehicle does not enhance intestinal uptake by itself. Paclitaxel $(10 \mathrm{mg} / \mathrm{kg})$ in SMEOF\#3 given with CsA resulted
\end{abstract}

\section{R. L. Oostendorp · J. H. M. Schellens}

Division of Experimental Therapy,

The Netherlands Cancer Institute,

Plesmanlaan 121,

1066CX Amsterdam, The Netherlands

R. L. Oostendorp

e-mail: roosoostendorp@hotmail.com

T. Buckle $\cdot$ O. van Tellingen $(\bowtie)$

Clinical Chemistry, The Netherlands Cancer Institute,

Plesmanlaan 121 ,

1066CX Amsterdam, The Netherlands

e-mail: o.v.tellingen@nki.nl

G. Lambert · J. S. Garrigue

Novagali Pharma S.A.,

Batiment Genavir IV, 1 rue Pierre Fontaine,

FR-91058 Evry Cedex, France in plasma levels that were comparable to the Cremophor ELethanol containing drinking solution plus CsA. Whereas the AUC increased linearly with the oral paclitaxel dose in P-glycoprotein knockout mice, it increased less than proportional in wild-type mice given with CsA. In both strains more unchanged paclitaxel was recovered in the feces at higher doses. This observation most likely reflects more profound precipitation of paclitaxel within the gastro-intestinal tract at higher doses. The resulting absolute reduction in absorption of paclitaxel from the gut was possibly concealed by partial saturation of first-pass metabolism when P-glycoprotein was absent. In conclusion, SMEOF's maybe a useful vehicle for oral delivery of paclitaxel in combination with CsA, although the physical stability within the gastro-intestinal tract remains a critical issue, especially when applied at higher dose levels.

Keywords Oral paclitaxel - SMEOF formulation . Cyclosporin A. Oral bioavailability

\section{J. H. Beijnen · J. H. M. Schellens}

Faculty of Science, Department of Pharmaceutical Sciences, Division of Biomedical Analysis, Utrecht University,

Sorbonnelaan 16 ,

3584CA Utrecht, The Netherlands

J. H. Beijnen

Depatment of Pharmacy, The Netherlands Cancer Institute, Louwesweg 6,

1066 EC Amsterdam, The Netherlands

J. H. M. Schellens

Medical Oncology, The Netherlands Cancer Institute,

Plesmanlaan 121,

1066CX Amsterdam, The Netherlands 


\section{Introduction}

Paclitaxel is a widely used anticancer agent that is administered by an intravenous (i.v.) infusion [1, 2]. Because the drug is poorly soluble in most pharmaceutical solvents it is formulated at a concentration of $6 \mathrm{mg} / \mathrm{ml}$ in a 1:1 mixture of Cremophor ${ }^{\circledR}$ EL (CrEL) and ethanol. Consequently, substantial amounts of these excipients are co-infused at the standard dose level of $175 \mathrm{mg} / \mathrm{m}^{2}$. However, CrEL has been associated with sometimes severe hypersensitivity reactions [3] and non-linear pharmacokinetic behaviour of i.v. administered paclitaxel [4-6].

In general, the oral route for the administration of drugs is considered to be more attractive than the i.v. route because of its greater convenience for patients and because of pharmacoeconomic advantages [7, 8]. In addition, the oral route facilitates repeated dosings, thereby prolonging the exposure time, which may be advantageous in case of cell cycle specific agents, such as paclitaxel. Unfortunately, however, oral dosing of paclitaxel is not a feasible option as paclitaxel has a very low oral bioavailability. This is mainly due to the action of the drug efflux transporter Pglycoprotein (P-gp) that is highly expressed in gastrointestinal tract and limits the uptake of drug from the intestinal lumen. Studies in mice have shown that whereas $87 \%$ of an orally administered dose of paclitaxel was recovered as unchanged drug in the feces of wild-type mice, excretion was reduced to $2 \%$ in P-gp knockout mice [9] indicating complete uptake from the gastro-intestinal tract when P-gp is absent. However, paclitaxel that does enter into the body is subjected to extensive first-pass metabolism by the gut and liver cytochrome P450 (CYP) enzymes (CYP2C8 and CYP3A4) [10], rendering the oral bioavailability in P-gp knockout mice about $40 \%$ [9]. In line with these results, concomitant administration of agents that block the function of P-gp and/or CYP, e.g. cyclosporin A (CsA), have successfully been used to increase the systemic exposure to the i.v. paclitaxel formulation after oral administration in mice and patients [11-13].

The design of an oral formulation of paclitaxel for use in patients remains a critical issue. So far, studies in patients have been conducted with the marketed formulation for i.v. administration, which is diluted with water before administration to yield an oral drinking solution [12, 14, 15]. Although these studies have shown that oral administration of paclitaxel is feasible and associated with antitumor efficacy [14-16], there are issues with the oral drinking solution that preclude its more widespread implementation in clinical practice. One of these concerns is the presence of substantial amounts of CrEL, which, when given at higher doses, antagonizes the absorption of paclitaxel from the GI tract [17-19] and for that reason, higher dose intensities can only be delivered by repeated administration. However,
CrEL gives the drinking solution an appalling taste resulting in intolerance, nausea and vomiting, especially when administered repeatedly. A possible solution to this issue may be to prepare a Self-Microemulsifying Oily Formulations (SMEOF) in which paclitaxel is encapsulated into $1-10 \mathrm{~nm}$ size oily droplets. The formulations consist of isotropic mixtures of oils and surfactants, which solubilize paclitaxel and spontaneously form a microemulsion upon contact with water. In a previous in vitro study the choice of the excipients was motivated by the particle size, physical and chemical stability as well as cytotoxicity of different selfemulsing drug delivery system formulations of paclitaxel [20]. In the different SMEOF formulations tyloxapol and TPGS (d-alpha-tocopheryl polyethylene glycol 1000 succinate) have been chosen for their ability to solubilize paclitaxel [20-23]. As compared to the commercial paclitaxel $\left(\operatorname{Taxol}^{\mathbb{R}}\right)$ formulation tested orally, the SMEOF formulations are CrEL-free and have a significantly lower ethanol to paclitaxel ratio.

The purpose of this preclinical study was to test the suitability of SMEOFs to serve as an oral delivery formulation of paclitaxel. We selected the most appropriate candidate for further investigations. In particular, we addressed the issue of the linearity of the relationship between the oral dose of paclitaxel and the systemic exposure.

\section{Material and methods}

\section{Chemicals and reagents}

SMEOF\#1 (1.5\%), SMEOF\#2 (3.0\%), SMEOF\#3 (1.5 or $3.0 \%$ ), SMEOF\#4 (1.5\%) (contents of paclitaxel between parenthesis; see Table 1 for compositions) were prepared by Novagali Pharma SA, (Evry Cedex, France). SMEOF\#4 is identical to SMEOF\#3, except that this formulation already contains cyclosporine $\mathrm{A}$ at a concentration of $1.5 \%$. Cyclosporin A (Sandimmune) originated from Novartis (Basel, Switzerland), Taxol ${ }^{\circledR}$ from Bristol-Meyers Squibb (München, Germany) and pure paclitaxel was obtained from Novagali. Polysorbate 80 was purchased from Brocacef B.V. (Maarssen, The Netherlands). All other chemicals were of analytical or lichrosolv gradient grade and originated from E. Merck (Darmstadt, Germany). Drug-free human plasma used for preparation of calibration curves [24] was obtained from the Central Laboratory of the Blood Transfusion Service (Sanquin, Amsterdam, The Netherlands).

\section{Animals}

Mice were housed and handled according to institutional guidelines complying with Dutch legislation. Animals 
Table 1 Composition of the different SMEOF formulations
- TPGS: d-alpha-tocopheryl polyethylene glycol 1000 succinate

- DOC-Na: Sodium desoxycholate

\begin{tabular}{|c|c|c|c|c|}
\hline \multirow{2}{*}{$\begin{array}{l}\text { Formulation } \\
\text { SMEOF\#1 (1.5\%) }\end{array}$} & \multirow[t]{2}{*}{ Component } & \multicolumn{2}{|c|}{ Percentage $\%(w / v)$} & \multirow[t]{2}{*}{ Function } \\
\hline & & Phase A & Phase B & \\
\hline & Paclitaxel & - & 1.5 & Active substance \\
\hline & Vitamin E & 5.00 & - & Oil \\
\hline & TPGS & 14.24 & 14.25 & Surfactant, co-solvent \\
\hline & Tyloxapol & 15.75 & 15.75 & Surfactant, co-solvent \\
\hline & Ethanol & 15.25 & 15.25 & Solvent \\
\hline & Doc-Na & 3.00 & - & Surfactant \\
\hline & Total & 53.24 & 46.75 & \\
\hline \multirow[t]{8}{*}{ SMEOF\#2 (3.0\%) } & & Phase A & Phase B & \\
\hline & Paclitaxel & - & 3.0 & Active substance \\
\hline & Vitamin E & 5.00 & - & Oil \\
\hline & TPGS & 14.00 & 14.00 & Surfactant, co-solvent \\
\hline & Tyloxapol & 15.50 & 15.50 & Surfactant, co-solvent \\
\hline & Ethanol & 15.00 & 15.00 & Solvent \\
\hline & Doc-Na & 3.00 & - & Surfactant \\
\hline & Total & 52.50 & 47.50 & \\
\hline \multirow[t]{7}{*}{ SMEOF\#3 $(1.5 \%$ and $3.0 \%)$} & & $(1.5 \%)$ & $(3.0 \%)$ & \\
\hline & Paclitaxel & 1.5 & 3.0 & Active substance \\
\hline & Vitamin E & 5.00 & 5.00 & Oil \\
\hline & TPGS & 29.95 & 29.45 & Surfactant, co-solvent \\
\hline & Tyloxapol & 33.05 & 32.55 & Surfactant, co-solvent \\
\hline & Ethanol & 30.5 & 30.0 & Solvent \\
\hline & Total & 100 & 100 & \\
\hline \multirow[t]{7}{*}{ SMEOF\#4 (1.5\%) } & Paclitaxel & 1.5 & & Active substance \\
\hline & Cyclosporin A & 1.5 & & P-gp inhibitor \\
\hline & Vitamin E & 5 & & Oil \\
\hline & TPGS & 29.45 & & Surfactant, co-solvent \\
\hline & Tyloxapol & 32.55 & & Surfactant, co-solvent \\
\hline & Ethanol & 30 & & Solvent \\
\hline & Total & 100 & & \\
\hline
\end{tabular}

used in all experiments were female $\mathrm{Mdrla} / 1 \mathrm{~b}^{-/-}$(P-gp knockout) and wild-type (WT) mice of FVB genetic background between 10 and 16 weeks of age. Animals were kept in a temperature-controlled environment with a 12-hour light/12-hour dark cycle. They received a standard diet (AM-II, Hope Farms, Woerden, The Netherlands) and acidified water ad libitum.

\section{Drug solutions}

SMEOF\#1, SMEOF\#2 are two-phase formulations that were quantitatively mixed just prior to 10 -fold dilution in sterile water while SMEOF\#4 working solution was also prepared by 10 -fold dilution in water. Final paclitaxel concentrations were $1.5,3.0$, and $1.5 \mathrm{mg} /$ $\mathrm{mL}$ for SMEOF\# 1, 2 and 4, respectively. SMEOF\#3 $(1.5 \%)$ was diluted 5 and 10-fold, while SMEOF\#3 $(3.0 \%)$ was diluted 10 and 20-fold with water for injection to yield final concentrations of 3.0 and $1.5 \mathrm{mg} / \mathrm{mL}$ of paclitaxel, respectively. Cyclosporin A (CsA) $50 \mathrm{mg} / \mathrm{mL}$ was diluted 25-fold with water for injection. Taxol ${ }^{\circledR}$ (paclitaxel; $6 \mathrm{mg} / \mathrm{ml}$ in CrEL:Ethanol $1: 1 ; v / v)$ was diluted 4-fold with water for injection. Paclitaxel $(6 \mathrm{mg} / \mathrm{ml})$ in polysorbate/ethanol $(1: 1 ; v / v)$ was prepared at our institute and was diluted 4-fold with saline for injection.

Plasma pharmacokinetics and oral bioavailability

In the first part of the study, cohorts of WT mice were treated orally with one of the four different SMEOF working solutions and $\operatorname{Taxol}^{\circledR}$ as a reference at a dose level of $10 \mathrm{mg} / \mathrm{kg}$ of paclitaxel. Separate cohorts of mice received paclitaxel (formulated in Polysorbate 80: ethanol) i.v. in order to calculate the absolute bioavailability. Polysorbate 80-ethanol and not the standard i.v. 
formulation of CrEL-ethanol was used to avoid the CrEL mediated nonlinear plasma pharmacokinetics of paclitaxel $[4,5]$. Oral drug administrations were given by gavage into the stomach. The SMEOF solutions were aliquoted in small portions in order to have fresh and clear drug solutions for all animals. By working this way we avoided precipitation from the formulation that sometimes occurred within minutes after the gavage. The animals were treated with or without concomitant administration of CsA (10 mg/kg), given at $20 \mathrm{~min}$ prior to oral paclitaxel or $30 \mathrm{~min}$ prior to i.v. paclitaxel. No concomitant CsA was given to animals receiving SMEOF\#4 as this formulation already contains CsA. In the second part, WT and P-gp knockout mice received paclitaxel in SMEOF\#3 at dose levels of 10, 30 and $60 \mathrm{mg} / \mathrm{kg}$. The WT mice also received oral CsA (10 mg/ $\mathrm{kg}$ ), 20 min prior to oral paclitaxel. An additional cohort of P-gp knockout mice received i.v. paclitaxel formulated in Polysorbate 80 : ethanol $(1: 1 ; v / v)$. In the third part, the properties of SMEOF\#3 (containing $30 \mathrm{mg} / \mathrm{ml}(3 \%, w / w)$ of paclitaxel) was investigated in P-gp knockout mice. These animals received dose levels of 10, 30 and $60 \mathrm{mg} /$ $\mathrm{kg}$. In all these pharmacokinetic experiments, five animals per time point were euthanized for blood sampling by cardiac puncture at $1,2,4$, and $8 \mathrm{~h}$ after administration. The plasma fraction of the blood samples was collected after centrifugation at $5,000 \times \mathrm{g}$ for $10 \mathrm{~min}$ at $4{ }^{\circ} \mathrm{C}$, and stored at $-20^{\circ} \mathrm{C}$ until analysis.

\section{Fecal excretion}

WT and P-gp knockout mice were individually housed in Ruco Type M/1 metabolic cages (Valkenswaard, The Netherlands). They were first accustomed to the cages for 2 days before receiving paclitaxel in SMEOF\#3 $(1.5 \%)$ working solution at dose levels of 10, 30 and $60 \mathrm{mg} / \mathrm{kg}$ (five animals per dose). The WT mice also received CsA (10 $\mathrm{mg} / \mathrm{kg}), 20 \mathrm{~min}$ prior to oral paclitaxel. Additionally, P-gp knockout mice received paclitaxel orally in SMEOF\#3 (3.0\%) paclitaxel at dose levels of 10,30 and $60 \mathrm{mg} / \mathrm{kg}$ (five animals per dose). The feces were collected every $24 \mathrm{~h}$ for up to $96 \mathrm{~h}$. Feces were pooled per animal and homogenized in $4 \%$ $(w / v) \mathrm{BSA}$ in water. The samples were stored at $-20^{\circ} \mathrm{C}$ until analysis.

\section{Drug analysis}

Amounts of paclitaxel in all biological samples were determined using a previously described validated highperformance liquid chromatography assay [24, 25] with a lower limit of quantification of $25 \mathrm{ng} / \mathrm{ml}$ using $250 \mu \mathrm{l}$ of sample.
Pharmacokinetic and statistical analysis

Pharmacokinetic parameters were calculated by noncompartmental methods using the software package Quattro Pro (Corel Corp., 1996; version 6.02). The area under the plasma concentration-time curve (AUC) was calculated from time $=0$ to the time of the last sampling point with a concentration above the LLQ $\left(\mathrm{C}_{\text {last }}\right)$ using the linear trapezoidal rule without extrapolation to infinity using the formula

$\mathrm{AUC}=\sum_{i=2}^{n}$ Concentration $_{\mathrm{i}} \cdot \frac{\left(\Delta \mathrm{time}_{i-1}+\Delta \mathrm{time}_{i}\right)}{2}$

with $\Delta$ time $_{n}=0$

The standard error (SE) of the AUC was calculated with the law of propagation of errors using the formula:

$\mathrm{SE}_{\mathrm{AUC}}=\sqrt{\left(\sum_{i=2}^{n} \mathrm{SE}_{\mathrm{i}} \cdot \frac{\left(\Delta \mathrm{time}_{i-1}+\Delta \mathrm{time}_{i}\right)^{2}}{4}\right)}$

The maximal plasma concentration $\left(\mathrm{C}_{\max }\right)$ and the time at which the maximal plasma level was reached $\left(\mathrm{T}_{\max }\right)$ were determined graphically. The oral bioavailability (F) was calculated using the formulas:

$\mathrm{F}=\left(\mathrm{AUC}_{\text {oral }} / \mathrm{AUC}_{\text {i.v. }}\right) * 100 \%$

The $\mathrm{SE}_{(\mathrm{F})}$ was calculated using:

$$
\begin{aligned}
\mathrm{SE}_{(\mathrm{F})}= & \mathrm{F} \cdot\left(\mathrm{SE}_{(\mathrm{AUC}, \text { oral })} / \mathrm{AUC}_{\text {oral }}\right)^{2} \\
& +\left(\mathrm{SE}_{\left(\mathrm{AUC}_{\text {i.v. }}\right)} / \mathrm{AUC}_{\text {i.v. }}\right)^{2}
\end{aligned}
$$

The unpaired Student's $t$-test (two-tailed) was used to compare the pharmacokinetic parameters. $P$-values $<0.05$ were considered statistically significant.

\section{Results}

Plasma pharmacokinetics of oral paclitaxel formulated in different SMEOFs in Wild-type and P-gp knockout mice

We first compared the oral bioavailability of paclitaxel in the four different SMEOF working solutions using the standard Taxol $^{\circledR}$ solution as reference. To determine the systemic exposure after i.v. injection we used paclitaxel formulated in polysorbate 80-ethanol instead of the standard CrEL-ethanol formulation in order to avoid the nonlinear pharmacokinetic behavior of paclitaxel in this vehicle [4, 5]. As expected, the paclitaxel plasma levels were low with all tested oral SMEOF working solutions when administered without CsA (Table 2 and Fig. 1). In combination with CsA, SMEOF\#1 and SMEOF\#2 resulted in a lower paclitaxel exposure when 
Table 2 Plasma pharmacokinetic parameters of paclitaxel $(10 \mathrm{mg} / \mathrm{kg})$ after oral treatment of the different SMEOF formulations (SMEOF\#1 SMEOF\#4, $1.5 \% \mathrm{w} / \mathrm{w}$ paclitaxel) and Taxol ${ }^{\circledR}$ or after i.v. administration

\begin{tabular}{|c|c|c|c|c|}
\hline Paclitaxel formulation & $\begin{array}{l}\text { Paclitaxel concentration, } \\
\text { administration route }\end{array}$ & $\begin{array}{l}\text { Cyclosporin A, } \\
\text { administration route }\end{array}$ & $\begin{array}{l}\mathrm{AUC}_{0-\text { Tlast }} \\
\left(\mathrm{ng} / \mathrm{mL}^{*} \mathrm{~h}\right)\end{array}$ & $\mathrm{F}(\%)$ \\
\hline SMEOF\#1 & $10 \mathrm{mg} / \mathrm{kg}$, p.o. & - & $306 \pm 46$ & $5.2 \pm 0.8$ \\
\hline SMEOF\#1 & $10 \mathrm{mg} / \mathrm{kg}$, p.o. & $10 \mathrm{mg} / \mathrm{kg}$, p.o. & $1652 \pm 181$ & $12.0 \pm 1.4$ \\
\hline SMEOF\#2 & $10 \mathrm{mg} / \mathrm{kg}$, p.o. & - & $173 \pm 40$ & $2.9 \pm 0.7$ \\
\hline SMEOF\#2 & $10 \mathrm{mg} / \mathrm{kg}$, p.o. & $10 \mathrm{mg} / \mathrm{kg}$, p.o. & $1480 \pm 160$ & $10.8 \pm 1.3$ \\
\hline SMEOF\#3 & $10 \mathrm{mg} / \mathrm{kg}$, p.o. & - & $108 \pm 17$ & $1.8 \pm 0.3$ \\
\hline SMEOF\#3 & $10 \mathrm{mg} / \mathrm{kg}$, p.o. & $10 \mathrm{mg} / \mathrm{kg}$, p.o. & $2534 \pm 177$ & $18.4 \pm 1.6$ \\
\hline SMEOF\#4 & $10 \mathrm{mg} / \mathrm{kg}$, p.o. & $10 \mathrm{mg} / \mathrm{kg}$, p.o. & $2769 \pm 307$ & $20.1 \pm 2.7$ \\
\hline \multirow[t]{2}{*}{ Taxol $^{\circledR}$} & $10 \mathrm{mg} / \mathrm{kg}$, p.o. & - & $417 \pm 64$ & $7.1 \pm 1.2$ \\
\hline & $10 \mathrm{mg} / \mathrm{kg}$, p.o. & $10 \mathrm{mg} / \mathrm{kg}$, p.o. & $2984 \pm 173$ & $21.7 \pm 1.6$ \\
\hline \multirow[t]{2}{*}{ Polysorbate $80 \mathrm{EtOH}$} & $10 \mathrm{mg} / \mathrm{kg}$, i.v. & - & $5862 \pm 366$ & $\mathrm{n} / \mathrm{a}$ \\
\hline & $10 \mathrm{mg} / \mathrm{kg}$, i.v. & $10 \mathrm{mg} / \mathrm{kg}$, p.o. & $13754 \pm 670$ & $\mathrm{n} / \mathrm{a}$ \\
\hline
\end{tabular}

$\mathrm{AUC}_{0-\infty}$ Area under the concentration time curve from 0 to the last time point with a concentration above the LLQ (Tlast), F oral bioavailability, $\mathrm{n} / \mathrm{a}$ not applicable

compared with the standard Taxol ${ }^{\circledR}$ formulation. Moreover, some turbidity of the diluted SMEOF\#1 and \#2 paclitaxel formulations started to occur within minutes after the first administration. For these reasons, and because these twoPhase systems were less convenient, the development of SMEOF\#1 and \#2 was discontinued. The administration of paclitaxel formulated in SMEOF\#3 in combination with CsA and of SMEOF\#4 (which contains CsA) resulted in systemic exposures that were similar to those obtained

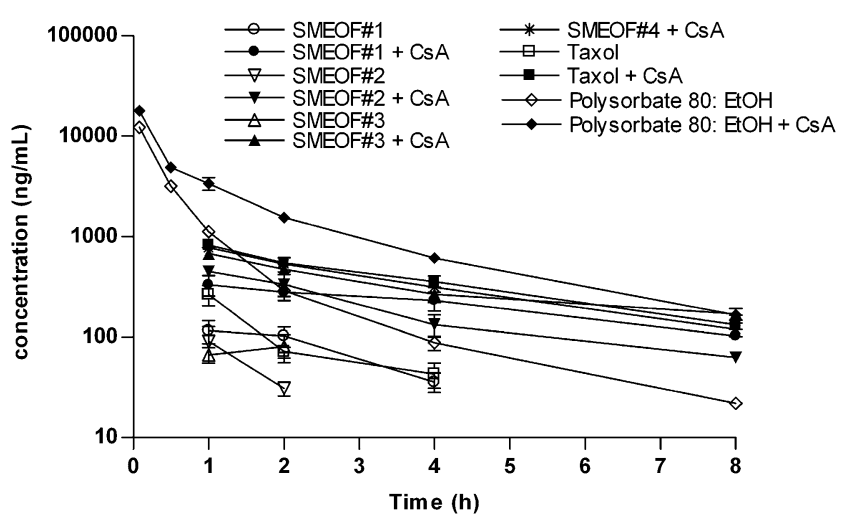

Fig. 1 Paclitaxel plasma concentration versus time curves after oral administration of different SMEOF (SMEOF\#1-SMEOF\#4, 1.5\% $w / w$ paclitaxel) formulations and $\mathrm{Taxol}^{\circledR}$ or i.v. administration of paclitaxel in a Polysorbate 80: ethanol solution in wild-type with or without co-administration of Cyclosporin A $(10 \mathrm{mg} / \mathrm{kg})$. Plasma levels of paclitaxel were determined by a validated HPLC method with lower limit of quantification $(25 \mathrm{ng} / \mathrm{mL})$. Data points are expressed as mean concentrations for oral and i.v. $(n=5)$ administration; error bars indicate Standard Errors (SEs) with the standard $\operatorname{Taxol}^{\circledR}$ formulation (Table 2 and Fig. 1). The oral bioavailability ranged from 18.4 to $21.7 \%$. Turbidity was not observed in these samples. In conclusion, the results of this study showed that the formulations SMEOF\#3 and SMEOF\#4 in combination with CsA are promising alternatives to the standard Taxol ${ }^{\circledR}$ formulation. In the next mouse experiments we have chosen to further explore the SMEOF\#3 paclitaxel formulation in combination with CsA.

Systemic exposure of paclitaxel formulated in SMEOF\#3 in wild-type and P-gp knockout mice

When P-gp knockout mice received SMEOF\#3 (1.5\%) orally at doses of 10,30 , or $60 \mathrm{mg} / \mathrm{kg}$ of paclitaxel, the exposure (AUC) increased in a dose-proportional manner (Table 3 and Fig. 2). The mean oral bioavailability of paclitaxel ranged from 29.9 to $38.6 \%$. Figure 3 reveals that the $\mathrm{T}_{\max }$ is longer at higher dose levels. When WT mice received SMEOF\#3 at 10, 30, or $60 \mathrm{mg} / \mathrm{kg}$ of paclitaxel in combination with CsA $(10 \mathrm{mg} / \mathrm{kg})$, the increase in the exposure to paclitaxel was not proportional with dose. Consequently, the absolute bioavailability decreased at higher dose levels (Table 3; Fig. 2). Overall, the exposure to paclitaxel in WT mice treated at a dose of $10 \mathrm{mg} / \mathrm{kg}$ of paclitaxel in combination with CsA was similar as in P-gp knockout mice treated with $10 \mathrm{mg} / \mathrm{kg}$ of paclitaxel in SMEOF\#3. Since the concomitant oral administration of CsA $(10 \mathrm{mg} / \mathrm{kg})$ also increased the exposure of i.v. administered paclitaxel, the oral bioavailability in WT mice was lower (Table 2). Similar as 
Table 3 Plasma pharmacokinetic parameters of paclitaxel after oral treatment of the SMEOF\#3

formulation (with $1.5 \% \mathrm{w} / \mathrm{w}$ and $3.0 \% \mathrm{w} / \mathrm{w}$ paclitaxel) at different doses of 10,30 , or $60 \mathrm{mg} / \mathrm{kg}$ or after i.v. administration of paclitaxel in a Polysorbate80: ethanol solution in P-gp knockout and/or wild-type mice co-administered with or without Cyclosporin A $(10 \mathrm{mg} / \mathrm{kg})$. Data are mean \pm Standard error (SE), oral and i.v. administration $(n=5)$

$\mathrm{AUC}_{0 \text {-Tlast }}$ Area under the concentration time curve from 0 to the last time point with a concentration above the LLQ (Tlast), F oral bioavailability, $\mathrm{n} / \mathrm{a}$ not applicable

\begin{tabular}{|c|c|c|c|c|}
\hline Paclitaxel formulation & Paclitaxel & Cyclosporin A & $\mathrm{AUC}_{0-\text { Tlast }}\left(\mathrm{ng} / \mathrm{mL}^{*} \mathrm{~h}\right)$ & $\mathrm{F}(\%)$ \\
\hline \multicolumn{5}{|l|}{ P-gp knockout mice } \\
\hline SMEOF\#3, (1.5\%) & $10 \mathrm{mg} / \mathrm{kg}$, p.o. & - & $1841 \pm 166$ & $29.9 \pm 3.1$ \\
\hline SMEOF\#3, (1.5\%) & $30 \mathrm{mg} / \mathrm{kg}$, p.o. & - & $7110 \pm 382$ & $38.6 \pm 2.8$ \\
\hline SMEOF\#3, (1.5\%) & $60 \mathrm{mg} / \mathrm{kg}$, p.o. & - & $11220 \pm 1131$ & $30.4 \pm 3.4$ \\
\hline Polysorbate $80: \mathrm{EtOH}$ & $10 \mathrm{mg} / \mathrm{kg}$, i.v. & - & $6147 \pm 291$ & $\mathrm{n} / \mathrm{a}$ \\
\hline \multicolumn{5}{|l|}{ Wild-type mice } \\
\hline SMEOF\#3, (1.5\%) & $10 \mathrm{mg} / \mathrm{kg}$, p.o. & $10 \mathrm{mg} / \mathrm{kg}$, p.o. & $2090 \pm 174$ & $15.2 \pm 1.5$ \\
\hline SMEOF\#3, $(1.5 \%)$ & $30 \mathrm{mg} / \mathrm{kg}$, p.o. & $10 \mathrm{mg} / \mathrm{kg}$, p.o. & $3835 \pm 430$ & $9.3 \pm 1.1$ \\
\hline SMEOF\#3, (1.5\%) & $60 \mathrm{mg} / \mathrm{kg}$, p.o. & $10 \mathrm{mg} / \mathrm{kg}$, p.o. & $5916 \pm 765$ & $7.2 \pm 1.0$ \\
\hline Polysorbate $80 \mathrm{EtOH}$ & $10 \mathrm{mg} / \mathrm{kg}$, i.v. & $10 \mathrm{mg} / \mathrm{kg}$, p.o. & $13754 \pm 670$ & $\mathrm{n} / \mathrm{a}$ \\
\hline \multicolumn{5}{|l|}{ P-gp knockout mice } \\
\hline SMEOF\#3, $(3.0 \%)$ & $10 \mathrm{mg} / \mathrm{kg}$, p.o. & & $1710 \pm 131$ & $27.8 \pm 2.5$ \\
\hline SMEOF\#3, $(3.0 \%)$ & $30 \mathrm{mg} / \mathrm{kg}$, p.o. & & $3871 \pm 621$ & $21.0 \pm 3.5$ \\
\hline SMEOF\#3, $(3.0 \%)$ & $60 \mathrm{mg} / \mathrm{kg}$, p.o. & & $1764 \pm 168$ & $4.8 \pm 0.5$ \\
\hline
\end{tabular}

observed in P-gp knockout mice the $\mathrm{T}_{\max }$ was delayed at the higher dose levels.

When P-gp knockout mice received the SMEOF\#3 with a higher load of paclitaxel SMEOF\#3 (3\%) the oral bioavailability at $10 \mathrm{mg} / \mathrm{kg}$ was similar to that observed
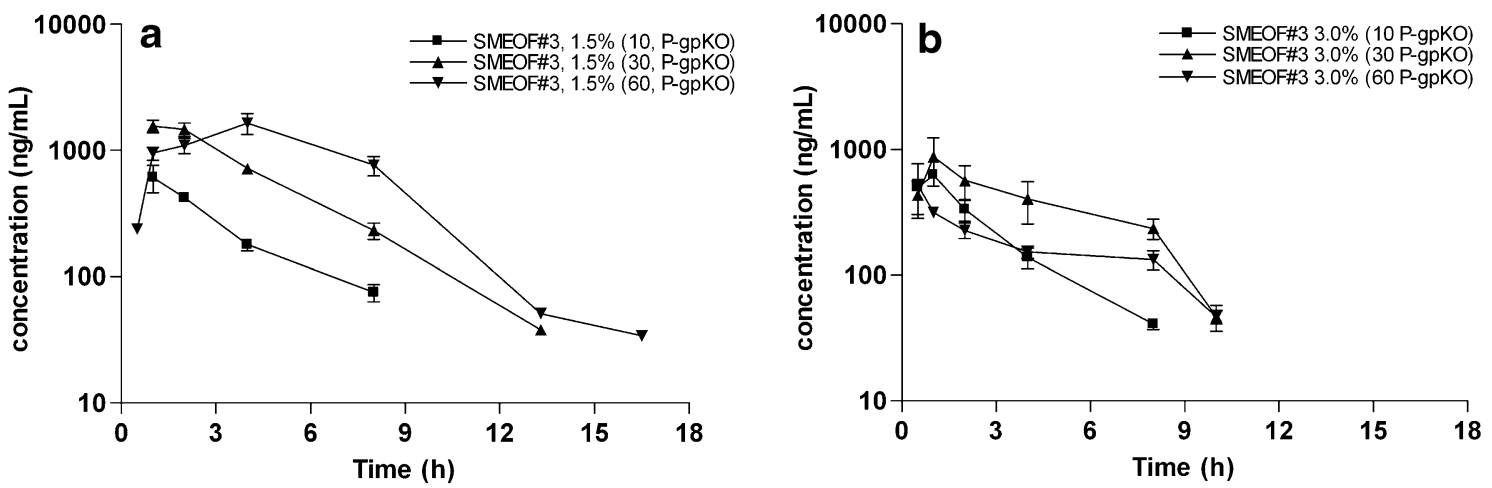

using SMEOF\#3 (1.5\%) (Table 3; Fig. 2). However, the oral bioavailability decreased markedly when higher dose levels were administered. Moreover, turbidity was also observed in the diluted formulations within 5 to $15 \mathrm{~min}$ after the first administration.

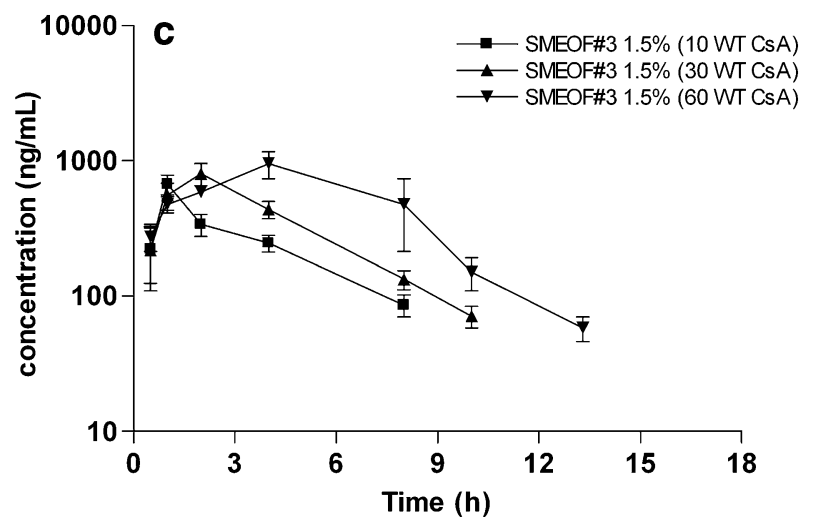

Fig. 2 Paclitaxel plasma concentration versus time curves after oral administration of the SMEOF\#3 formulation with $1.5 \% w / w$ and $3.0 \%$ $w / w$ paclitaxel at different doses of 10,30 , or $60 \mathrm{mg} / \mathrm{kg}$ in P-gp knockout (a and b) and wild-type mice (c) co-administered with Cyclosporin A $(10 \mathrm{mg} / \mathrm{kg})$. Plasma levels of paclitaxel were determined by a validated HPLC method with lower limit of quantification $(25 \mathrm{ng} / \mathrm{mL})$. Data points are expressed as mean concentrations for oral $(n=5)$ administration; error bars indicate Standard Errors (SEs) 


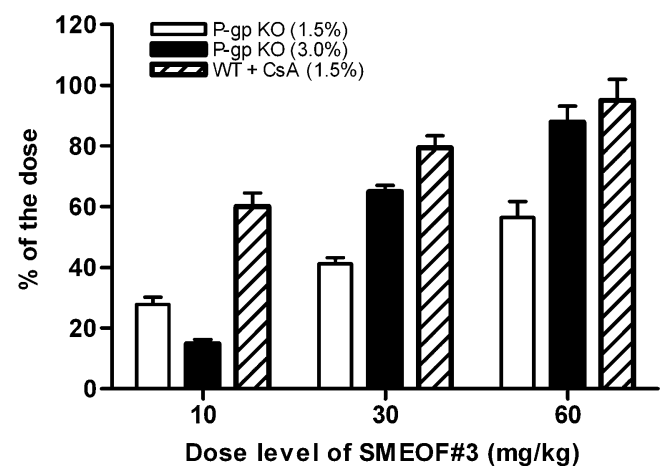

Fig. 3 Fecal excretion of paclitaxel in P-gp knockout and Wild-type mice co-administered with CsA $(10 \mathrm{mg} / \mathrm{kg})$. The mice were housed in metabolic cages and were treated with an oral administration of SMEOF\#3 (with $1.5 \% \mathrm{w} / \mathrm{w}$ or $3.0 \% \mathrm{w} / \mathrm{w}$ paclitaxel) at different doses of 10,30 , or $60 \mathrm{mg} / \mathrm{kg}$. Paclitaxel levels were measured in feces excreted between 0-96 h using a validated HPLC method. Results are expressed as percentage of the given dose; Bars \pm SE $(n=5)$

Fecal excretion of the paclitaxel formulated in SMEOF\#3 in Wild-type and P-gp knockout mice

When SMEOF\#3 (1.5\%) was administered orally at doses of 10,30 , or $60 \mathrm{mg} / \mathrm{kg}$ of paclitaxel to P-gp knockout mice, the recovery of unchanged paclitaxel in the feces increased with dose from $27.9 \% \pm 2.4 \%$ to $56.4 \pm 5.3 \%$ of the administered dose, whereas the recovery ranged up to $84.7 \% \pm 5.2 \%$ when using SMEOF\#3 (3\%)(Fig. 3). Thus, the fecal recovery of paclitaxel in P-gp knockout mice was considerably higher with SMEOF\#3 (3.0\%) than with SMEOF\#3 $(1.5 \%)$, which is in line with the finding that the plasma concentration and oral bioavailability of paclitaxel in SMEOF\#3 (3\%) was lower. The fecal excretion of paclitaxel in WT mice receiving SMEOF\#3 $(1.5 \%)$ in combination with CsA, increased with dose from 60.1 to $95.0 \%$ (Fig. 3), indicating that intestinal P-gp was not completely inhibited by CsA.

\section{Discussion}

The present study shows that SMEOFs are potentially suitable as delivery vehicles for oral administration of paclitaxel when administered in combination with a P-gp inhibitor such as CsA. We selected SMEOF\#3 for more extensive studies because the systemic exposure and bioavailability of paclitaxel after oral administration of SMEOF\#3 was comparable to the standard drinking solution containing Cremophor EL:ethanol $\left(\right.$ Taxol $\left.^{\circledR}\right)$. The oral bioavailability of paclitaxel in mice receiving the drinking solution is about $40 \%$ [9], which is a good starting point. For patients, however, the drinking solution suffers from an unacceptable bitter taste and also leads to a high concomitant ethanol consumption. Moreover, in patients the bioavailability is reduced when higher dose levels are given [19]. SMEOF\#1 and \#2 are less practical since they are two-phase solutions that require mixing prior to administration. Moreover, it appeared that they were less stable, which resulted in lower exposures when compared to SMEOF\#3. SMEOF\#4 is identical to SMEOF\#3, except that it already contains CsA and was at least as good as SMEOF\#3. Although such a combination of paclitaxel and a P-gp/CYP450 inhibitor in one formulation holds attractive perspectives for future clinical implementation, it was considered more appropriate to use the single drug formulation in this preclinical-mechanistic investigation.

There are two major issues that need to be addressed in order to achieve adequate exposure of paclitaxel after oral administration. The first issue is that it is essential to block and/or bypass the action of P-gp in the intestinal wall as this drug transporter is mainly responsible for the negligible uptake of paclitaxel by the enterocytes [9]. Changing the formulation from a system of co-solvents to a SMEOF was not sufficient to bypass P-gp as the exposure of paclitaxel in WT mice receiving paclitaxel in various SMEOF's without concomitant CsA was very low. Consequently, a combination of paclitaxel in SMEOFs with a P-gp inhibitor is mandatory to yield acceptable oral bioavailabilities.

The second issue concerns the composition and stability of the formulation in the gastro-intestinal tract, as this determines the rate at which paclitaxel will be released from the carrier and becomes available for uptake through the intestinal wall. If degradation of the carrier occurs too slowly, as with CrEL, a substantial fraction of the dose will leave the body without having had the opportunity for uptake by enterocytes [17]. On the other hand, if the release from the carrier occurs too rapidly, there is a chance of irreversible precipitation of the liberated and water-insoluble paclitaxel molecules within the intestinal lumen. By using P-gp knockout mice we were able to study this latter issue without having to take into account the action of P-gp.

The plasma pharmacokinetics and fecal excretion of paclitaxel were evaluated at three different dose levels in P-gp knockout mice. At the lowest dose level of $10 \mathrm{mg} / \mathrm{kg}$ the plasma AUC is very similar to the AUC achieved in patients receiving oral paclitaxel in the CrEL containing drinking solution together with oral CsA $(1.5-3.5 \mu \mathrm{M} \bullet \mathrm{h} \approx$ 1,200-2,400 ng/ml•h) [19], although the direct comparison is somewhat tricky because the shape of the curves in mice and humans differ with higher $\mathrm{C}_{\max }$, shorter $\mathrm{T}_{\max }$ and shorter elimination half-life in mice. When patients receive increasing doses of oral paclitaxel, the plasma AUC increases only marginally because of entrapment of paclitaxel in CrEL micelles in the intestinal lumen [17, 18]. Although the finding that the plasma AUC of paclitaxel in mice increased proportional with dose when using SMEOF\#3 suggested that the uptake by the intestines 
was also independent of the dose, this was not the case. The fecal excretion of unchanged drug at the $10 \mathrm{mg} / \mathrm{kg}$ dose was already much higher than the less than $2 \%$ previously observed with the CrEL drinking solution [9] and the fecal excretion further increased with dose. Because the fecal excretion of unchanged drug was even more pronounced when the amount of carrier relative to paclitaxel was reduced as in SMEOF\#3 (3\%), it is most likely that a rapid degradation of the carrier is responsible for the reduced intestinal uptake. Apparently, this formulation may not be stable enough to contain paclitaxel at this concentration in order to protect paclitaxel from precipitation in the gastrointestinal tract. Moreover, gastric emptying in mice was delayed at the higher dose levels, as indicated by the longer $\mathrm{T}_{\max }$, leaving even more time for degradation of the carrier before the drug enters into the intestines. In view of this, the finding that the plasma level of paclitaxel increased doseproportionally, in spite of the fact that the uptake at higher dose levels occurs less efficiently, is most likely caused by saturation of first-pass metabolism at the higher doses. In a previous pilot study with SMEOF\#3 (1.6\%) in patients, it was observed that the AUC was similar, but that the $\mathrm{T}_{\max }$ was shorter and the $\mathrm{C}_{\max }$ was higher than with the CrEL drinking solution [26]. This finding is consistent with the idea that paclitaxel becomes more readily available for uptake when given in SMEOF\#3. As the load of paclitaxel in SMEOF\#3 appears to be an important determinant for the rate of release, future clinical studies aimed at establishing the dose-AUC proportionality of oral paclitaxel with SMEOF\#3 should include the testing of different loads.

As expected, the fecal recovery was higher in WT mice due to reduced intestinal uptake because of incomplete inhibition of P-gp by CsA. We have used a dose level of $10 \mathrm{mg} / \mathrm{kg}$ of CsA because we previously found that increasing the dose to $50 \mathrm{mg} / \mathrm{kg}$ did not further increase the oral bioavailability [12]. Moreover, this lower dose was preferred because we wanted to avoid as much as possible an interaction between the SMEOF and CrEL that is present in the CsA formulation. For this reason there was also a $20 \mathrm{~min}$ lag time between the two subsequent oral administrations. Incomplete inhibition of P-gp was more pronounced at higher dose levels of SMEOF\#3. Whereas it is possible that the dose level of CsA was too low to compete for the higher quantities of paclitaxel, it is also likely that it is a consequence of the delayed gastric emptying. Due to this effect, CsA that was given $20 \mathrm{~min}$ prior to paclitaxel had already moved to lower parts of the intestinal tract when a substantial fraction of the dose of paclitaxel was still present in the stomach. Both the dose and the timing issues would be addressed when the formulation would hold both paclitaxel and the inhibitor as in SMEOF\#4 and this is certainly an option to test in future clinical studies.
In conclusion, our preclinical mechanistic studies with oral administration of paclitaxel in novel SMEOFs showed that SMEOF\#3 is a potentially suitable vehicle for oral delivery of paclitaxel when given in combination with a P-gp inhibitor such as CsA. Our results revealed that the bioavailability and the systemic exposure to paclitaxel after a single oral administration of SMEOF\#3 were comparable to the standard Cremophor EL: ethanol formulations. The load of paclitaxel in the formulation appears to be important with respect to the stability of paclitaxel in the gastro-intestinal tract and can be used to optimize the bioavailability and dose-proportionality of systemic drug exposure after oral administration in future clinical studies.

Open Access This article is distributed under the terms of the Creative Commons Attribution Noncommercial License which permits any noncommercial use, distribution, and reproduction in any medium, provided the original author(s) and source are credited.

\section{References}

1. Huizing MT, Misser VH, Pieters RC, Bokkel Huinink WW, Veenhof CH, Vermorken JB, Pinedo HM, Beijnen JH (1995) Taxanes: a new class of antitumor agents. Cancer Invest 13:381404

2. Rowinsky EK, Wright M, Monsarrat B, Donehower RC (1994) Clinical pharmacology and metabolism of Taxol (paclitaxel): update 1993. Ann Oncol 5(Suppl 6):S7-S16, S7-16

3. Dorr RT (1994) Pharmacology and toxicology of Cremophor EL diluent. Ann Pharmacother 28:S11-S14

4. Sparreboom A, van Tellingen O, Nooijen WJ, Beijnen JH (1996) Nonlinear pharmacokinetics of paclitaxel in mice results from the pharmaceutical vehicle Cremophor EL. Cancer Res $56: 2112-2115$

5. van Tellingen O, Huizing MT, Panday VR, Schellens JH, Nooijen WJ, Beijnen JH (1999) Cremophor EL causes (pseudo-) nonlinear pharmacokinetics of paclitaxel in patients. $\mathrm{Br} \mathrm{J}$ Cancer 81:330-335

6. Sparreboom A, van Zuylen L, Brouwer E, Loos WJ, de Bruijn P, Gelderblom H, Pillay M, Nooter K, Stoter G, Verweij J (1999) Cremophor EL-mediated alteration of paclitaxel distribution in human blood: clinical pharmacokinetic implications. Cancer Res 59:1454-1457

7. Liu G, Franssen E, Fitch MI, Warner E (1997) Patient preferences for oral versus intravenous palliative chemotherapy. J Clin Oncol $15: 110-115$

8. Schellens JH, Malingre MM, Kruijtzer CM, Bardelmeijer HA, van Tellingen O, Schinkel AH, Beijnen JH (2000) Modulation of oral bioavailability of anticancer drugs: from mouse to man. Eur $\mathrm{J}$ Pharm Sci 12:103-110

9. Sparreboom A, van Asperen J, Mayer U, Schinkel AH, Smit JW, Meijer DK, Borst P, Nooijen WJ, Beijnen JH, van Tellingen O (1997) Limited oral bioavailability and active epithelial excretion of paclitaxel (Taxol) caused by P-glycoprotein in the intestine. Proc Natl Acad Sci USA 94:2031-2035

10. Sonnichsen DS, Liu Q, Schuetz EG, Schuetz JD, Pappo A, Relling MV (1995) Variability in human cytochrome P450 paclitaxel metabolism. J Pharmacol Exp Ther 275:566-575 
11. van Asperen J, van Tellingen O, Sparreboom A, Schinkel AH, Borst P, Nooijen WJ, Beijnen JH (1997) Enhanced oral bioavailability of paclitaxel in mice treated with the P-glycoprotein blocker SDZ PSC 833. Br J Cancer 76:1181-1183

12. van Asperen J, van Tellingen O, Van Der Valk MA, Rozenhart M, Beijnen JH (1998) Enhanced oral absorption and decreased elimination of paclitaxel in mice cotreated with cyclosporin A. Clin Cancer Res 4:2293-2297

13. Meerum Terwogt JM, Beijnen JH, Bokkel Huinink WW, Rosing H, Schellens JH (1998) Co-administration of cyclosporin enables oral therapy with paclitaxel. Lancet 352:285

14. Kruijtzer CM, Schellens JH, Mezger J, Scheulen ME, Keilholz U, Beijnen JH, Rosing H, Mathot RA, Marcus S, van Tinteren H, Baas P (2002) Phase II and pharmacologic study of weekly oral paclitaxel plus cyclosporine in patients with advanced non-smallcell lung cancer. J Clin Oncol 20:4508-4516

15. Kruijtzer CM, Boot $\mathrm{H}$, Beijnen JH, Lochs HL, Parnis FX, Planting AS, Pelgrims JM, Williams R, Mathot RA, Rosing H, Schot ME, van Tinteren H, Schellens JH (2003) Weekly oral paclitaxel as first-line treatment in patients with advanced gastric cancer. Ann Oncol 14:197-204

16. Helgason HH, Kruijtzer CM, Huitema AD, Marcus SG, Bokkel Huinink WW, Schot ME, Schornagel JH, Beijnen JH, Schellens JH (2006) Phase II and pharmacological study of oral paclitaxel (Paxoral) plus ciclosporin in anthracycline-pretreated metastatic breast cancer. Br J Cancer 95:794-800

17. Malingre MM, Schellens JH, van Tellingen O, Ouwehand M, Bardelmeijer HA, Rosing H, Koopman FJ, Schot ME, Bokkel Huinink WW, Beijnen JH (2001) The co-solvent Cremophor EL limits absorption of orally administered paclitaxel in cancer patients. Br J Cancer 85:1472-1477

18. Bardelmeijer HA, Ouwehand M, Malingre MM, Schellens JH, Beijnen JH, van Tellingen O (2002) Entrapment by Cremophor
EL decreases the absorption of paclitaxel from the gut. Cancer Chemother Pharmacol 49:119-125

19. Malingre MM, Terwogt JM, Beijnen JH, Rosing H, Koopman FJ, van Tellingen O, Duchin K, Huinink WW, Swart M, Lieverst J, Schellens JH (2000) Phase I and pharmacokinetic study of oral paclitaxel. J Clin Oncol 18:2468-2475

20. Gursoy N, Garrigue JS, Razafindratsita A, Lambert G, Benita S (2003) Excipient effects on in vitro cytotoxicity of a novel paclitaxel self-emulsifying drug delivery system. J Pharm Sci 92:2411-2418

21. Gershanik T, Benita S (2000) Self-dispersing lipid formulations for improving oral absorption of lipophilic drugs. Eur J Pharm Biopharm 50:179-188

22. Chang T, Benet LZ, Hebert MF (1996) The effect of water-soluble vitamin $\mathrm{E}$ on cyclosporine pharmacokinetics in healthy volunteers. Clin Pharmacol Ther 59:297-303

23. Boudreaux JP, Hayes DH, Mizrahi S, Maggiore P, Blazek J, Dick D (1993) Use of water-soluble liquid vitamin E to enhance cyclosporine absorption in children after liver transplant. Transplant Proc 25:1875

24. Sparreboom A, van Tellingen O, Nooijen WJ, Beijnen JH (1995) Determination of paclitaxel and metabolites in mouse plasma, tissues, urine and faeces by semi-automated reversed-phase highperformance liquid chromatography. J Chromatogr B Biomed Appl 664:383-391

25. Huizing MT, Sparreboom A, Rosing H, van Tellingen O, Pinedo HM, Beijnen JH (1995) Quantification of paclitaxel metabolites in human plasma by high-performance liquid chromatography. J Chromatogr B Biomed Appl 674:261-268

26. Veltkamp SA, Thijssen B, Garrigue JS, Lambert G, Lallemand F, Binlich F, Huitema AD, Nuijen B, Nol A, Beijnen JH, Schellens JH (2006) A novel self-microemulsifying formulation of paclitaxel for oral administration to patients with advanced cancer. Br J Cancer 95:729-734 